\title{
Canada demands action from United States on acid rain
}

Washington

THE Canadian government's quarrel with Washington over acid rain has moved into a new and more acrimonious phase, with the Canadians demanding immediate action. At a meeting on 21 January, the Canadian Prime Minister, Brian Mulrony, gave US vice-president George Bush what is described as an "earful" and declared that the issue of acid rain will be "at the top of the agenda" for his meeting with President Ronald Reagan in April.

US efforts so far to reduce acid rain

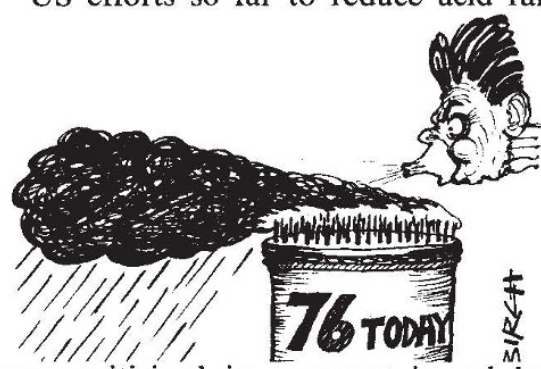

were criticized in a report issued last month by Canada's environment ministry. The US State Department has responded with another high-level review while efforts to improve control continue to focus on the long-range development of new and affordable technologies to reduce the pollution from coal smoke, with no immediate reduction of the amount of sulphur dioxide crossing the border.

US policy on acid rain continues to ignore the Canadian demand that it should control the pollutants responsible for acid rain, despite the report in January 1986, by two specially appointed envoys, which persuaded the Reagan administration to agree in principle that acid rain was a serious problem. Since then, Canada has been waiting for policy changes in the United States, but the new budget contains no new programmes to reduce sulphur dioxide emissions from coal-fired plants.

Instead, the US administration points to its recent clean-coal technology legislation, which is intended to reduce the cost of new techniques for removing pollutants from coal smoke. But no immediate reductions are required, while the new technology will probably be applied only as older power plants need refurbishment.

The Canadians are not alone in calling for changes in US policy. Two bills introduced in the Senate this month would require a significant tightening of US air pollution controls. The bills were backed by testimony from physicians such as Dr Richard Narkewicz, president-elect of the American Academy of Pediatrics, who stated that "the ingredients of acid rain adversely affect the respiratory tract and consequently the quality of health for children" and "contribute greatly to mortality rates". Further testimony indicated that air pollutants such as sulphur dioxide, nitrogen oxides and ozone put many others at risk, including people over 65 and sufferers from asthma and heart disease.

New political alignments in the Senate may prove to be insurmountable obstacles to the proposed legislation. Senate leaders from coal-producing states, for example, will probably provide strong opposition.

Although the administration no longer disputes the causal connection between sulphur dioxide pollution and environmental damage, it asserts that it is unclear at what rate the damage is being caused. "The argument can be made", said Chris Rice of the Environmental Protection Agency (EPA), "that the damage we see now is due to sulphur dioxide emitted in the 1950 s or 1960 s". But Debbie Sheiman of the Natural Resources Defense Council says "the administration seems to be using delaying tactics" to avoid using pollution control technology now available.

Renewed Canadian demands for US reductions of acid rain have directed attention to Canada's own acid rain reduction programme. The seven provinces east of Saskatchewan agreed in 1985 to reduce sulphur dioxide emissions by 50 per cent by 1994. Stricter emission controls on automobiles will take effect in September this year.

But some in the US Congress believe the Canadians are being hypocritical, as they have yet to begin installing pollution control devices on their own smokestacks. A Canadian government spokesman rejects this charge as irrelevant, because most sulphur dioxide pollution in Canada results from non-ferrous smelters, not power plants. The most effective (and most often used) control device for such a smelter is to shut it down, as was done with the International Nickel Company's plant at Sudbury, Ontario,for example.

The question of what will happen to sulphur dioxide emissions in Canada when economic conditions favour the continued operation of these plants remains open. Steven Dickman

\section{Atomic power struggle under way in India}

\section{New Delhi}

THE appointment of a successor to Dr Raja Ramanna, retiring chairman of the Indian Atomic Energy Commission (AEC), has been postponed at the last minute in the wake of threats of resignation and an internal power struggle between top scientists at

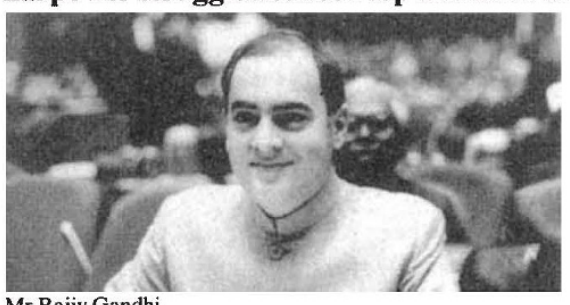

Mr Rajiv Gandhi

the Department of Atomic Energy (DAE). Whether an engineer or a physicist should be made head of the commission is the subject of a controversy that has brought to the fore the factional politics within DAE and the schism between research scientists and engineers. With two contenders vying for the post, an embarrassed Prime Minister, Mr Rajiv Gandhi, who is also in charge of atomic energy, has asked Ramanna to continue as chairman for a further month.

One of the aspirants for the post is Dr P.K. Iyengar, the director of the Bhabha Atomic Research Centre (BARC), which is the principal agency responsible for research and development. Iyengar, a reactor physicist and a key figure in the design and testing of India's first nuclear device, was Ramanna's student and his favourite for the post. The other contender is Dr M.R. Srinivasan, an engineer, who is in charge of DAE's nuclear power board, which is responsible for the design, construction and operation of nuclear power plants. Both Iyengar and Srinivasan are members of AEC.

Ramanna, who was to have retired on 31 January, was not told of his successor until the previous evening when he was told to hand over to Srinivasan. Twelve hours later the order was withdrawn, apparently because Iyengar threatened to resign. Ramanna was then asked to continue as chairman until the end of February and the prime minister presumably hopes that the delay will give him time to pacify Iyengar. Scientists at DAE, upset over the lastminute change, have openly accused Ramanna of blackmailing the government and stalling the appointment of Srinivasan, whose name had been proposed by a special selection committee.

Gandhi's handling of the issue has been attacked in the newspapers, which claim that it has lowered his credibility within the scientific community. Similar criticisms were voiced a few months ago when Gandhi abruptly removed Dr S. Varadarajan from his post as director-general of the Council of Scientific and Industrial Research.

The bitter taste left behind by the struggle over the succession at AEC will take time to wipe out, but Gandhi has already taken steps to bring peace among the warring scientists. He has held separate meetings with Iyengar, Srinivasan and Ramanna, and the name of the new AEC chairman is expected to be announced soon.

K.S. Jayaraman 